\title{
НЕЙРОГУМОРАЛЬНІ ПРОФІЛІ ТА ІНСУЛІНОРЕЗИСТЕНТНІСТЬ У ХВОРИХ НА АРТЕРІАЛЬНУ ГІПЕРТЕНЗІЮ БЕЗ ОЖИРІННЯ
}

\author{
Шевчук С. В. ${ }^{1}$, Корчинський В. С. ${ }^{2}$ \\ ${ }^{1}$ Науково-дослідний інститут реабілітації осіб з інвалідністю \\ Вінницького національного медичного університету і.м. М. І. Пирогова, \\ м. Вінниия, Украӥна \\ ${ }^{2}$ Вінницький інститут університету «Україна», м. Вінниия, Украӥна \\ doktor.k.v.s@gmail.com
}

Артеріальна гіпертензія (АГ) е одним із провідних фракторів ризику серцево-судинних захворювань (СC3) [1, 2]. Незважаючи на значний прогрес у розумінні механізмів розвитку АГ та удосконалення підходів до ї̈ лікування, вона залишаеться найбільш вагомою причиною смертності поміж факторів, які підлягають модифікації. Новим аспектом вивчення АГ е той фракт, що майже 1/3 хворих з самого початку і незалежно від маси тіла інсулінорезистентні $[3,4]$. Така комбінація фракторів ризику викликає розвиток запальних реакцій в тканинах, запускае і підтримуе ендотеліальну дисфункцію зі зниженням реакції ендотелію на вазодилятаційні і посиленням на вазоконстрикторні впливи [1, 5], викликає активацію ренін-ангіотензин-альдостеронової системи (РАAC) і симпато-адре- налової системи (САC) [3, 6], що пов'язано зі значним зростанням ризику СС3 [7, 8, $9,10]$.

Інсулінорезистентність (IP) розглядають як зниження чутливості тканин (м'язової, жирової і тканин печінки) до дії інсуліну, що призводить до порушення поглинання та утилізації глюкози, зменшення синтезу глікогену, активації глікогенолізу і глюконеогенезу [3, 9]. Ключовою ланкою розвитку IP є порушення ефектів інсуліну на рівні рецепторів, внутрішньоклітинних ланок і клітин-мішеней $[3,7]$. Це може бути пов'язано зі зниженням кількості інсулінових рецепторів, зменшенням активності тирозинкінази інсулінового рецептора, внаслідок чого сповільнюеться швидкість синтезу фосфатидилінозитол-3-кінази, що відповідае за транслокацію транспортерів

* Робота е фрагментом науково-дослідної роботи НДІ РОІ ВНМУ ім. М. І. Пирогова «Вивчити клінічні, метаболічні, генетичні та імунологічні чинники розвитку остеопорозу та саркопенії у хворих на системний червоний вовчак», державна реестрація № 0119U101281.

Установою, що фінансуе дослідження, е МОЗ України.

Автори гарантують повну відповідальність за все, що опубліковано в статті.

Автори гарантують відсутність конфлікту інтересів і власної фінансової зацікавленості у виконанні роботи та написанні статті.

Рукопис надійшов до редакції 11.08.2021. 
глюкози (GLUT-4) на плазматичну мембрану клітин інсулін-чутливих тканин [11, 12]. Важливу роль у розвитку IP відіграє запалення жирової тканини, що сприяє вивільненню прозапальних цитокінів, зокрема фрактору некрозу пухлин, який через інгібірування експресії GLUT-4 знижує утилізацію глюкози тканинами [6]. В неменшій мірі розвитку IP сприяють порушення утворення в жировій тканині адипоцитокінів, зокрема, для IP характерні гіпоадипонектинемія і гіперлептинемія $[6,13]$. В клітинах жирової тканини також активно експресуються всі компоненти PAAC, а ангіотензин II помітно гальмує адипогенну диференціацію преадипоцитів через рецептори 1-го типу. Активність експресії ангіотензинперетворюючого фрерменту зворотно корелює з чутливістю тканин до інсуліну [14]. Молекулярні та патофрізіологічні механізми, що лежать в основі взаємозв’язків між резистентністю до інсуліну, РАAC та гіпертонічною хворобою, призводять до порочного кола, яке підси- лює зв’язок між метаболічними та гемодинамічними порушеннями [6]. При цьому вегетативна дисфункція з перевагою симпатичного тонусу є незаперечною ланкою патогенезу IP, однак досліджень 3 комплексною оцінкою ролі вегетативної нервової системи недостатньо і вони суперечливі. Не дивлячись на проведені дослідження, патогенетичні зв'язки між IP, PAAC та іншими пресорними і депресорними системами, станом вегетативної нервової системи при АГ все ж таки залишаються не до кінця з'ясованими. Необхідні подальші дослідження для визначення впливу інсуліну, гіперінсулінемії, IP, вегетативної нервової системи на пресорні і депресорні механізми, які сприяють виникненню АГ.

Метою дослідження стало вивчення показників вуглеводного обміну, активності PAAC, глюкокортикоїдної фрункції наднирників, кальцій-регулюючих і тиреоїдних гормонів та їх можливих взаємозв'язків у хворих на АГ з IP в залежності від стану вегетативного тонусу.

\section{МАТЕРІАЛИ ТА МЕТОДИ}

Обстежено 68 чоловік, середній вік $53,7 \pm 3,4$ роки, з АГ II стадії, 1-2-го ступеня, з індексом маси тіла (IMT) до $30 \mathrm{\kappa r} / \mathrm{M}^{2}$, 3 верифікованою IP. Залежно від стану вегетативного тонусу хворі були розподілені на 2 групи: I група - 37 пацієнтів з перевагою симпатичного тонусу (IMT $-27,35 \pm$ $2,61)$, II група - 31 паціент з перевагою парасимпатичного тонусу (IMT $-26,43 \pm$ $2,85)$. Діагноз артеріальної гіпертензії встановлювали відповідно до рекомендацій Європейського товариства з АГ і Європейського товариства кардіологів (ESH/ESC, 2018) [10]. Інсулінорезистентність верифікували за величиною індексу Caro (глюкоза, ммоль/л/інсулін, мкОд/мл), що не перевищувала 0,33 . У дослідження не включали хворих з ішемічною хворобою серця, симптоматичними гіпертензіями, ожирінням, цукровим діабетом, порушеною толерантністю до вуглеводів. Хворим на АГ II стадії за 5 днів до обстеження відміняли антигіпертензивні препарати (інгібітори АПФ, сартани, антагоністи кальцію, діуретики). До контрольної групи включено
34 практично здорових осіб, порівнянних за віком і IMT. Дослідження гемодинаміки і нейрогуморального профілю проводили за розробленою нами раніше методикою [15]. Показники центральної гемодинаміки (ударний та серцевий індекси) вивчали методом ехокардіографії в В-режимі за модифікованою методикою Simpson на апараті My Lab-40 (Biomedical, Італія). Дослідження гемодинаміки проводили вранці, натщесерце, після 30-хвилинного перебування в горизонтальному положенні. У цих же умовах брали кров із ліктьової вени. У сироватці крові радіоімунним методом визначали активність реніну плазми (АРП), ангіотензину II (AII), вміст альдостерону (КАП), кальцитоніну (КТ), паратгормону (ПТГ), тиреотропного гормону (ТТГ), тироксину (Т, $\left(\mathrm{T}_{3}\right)$, інсуліну (IPI), кортизолу (ККП), прогестерону (ПГ). Аналізи проводили з використанням наборів фрірм «Cea-Ire-Sorin» (Франція), «Ria-mat» (Німеччина), «Nen» (США), «Аmersham» (Великобританія), Інституту біоорганічної хімії АН Білорусі. 
Показники електролітного обміну (вміст у плазмі іонізованого кальцію, магнію) вивчали іоноселективним методом за допомогою мікроліта фірми «Копе», вміст глюкози в капілярній крові - глюкозооксидазним методом.

Для оцінки стану вегетативної нервової системи проводили варіаційну пульсометрію за методикою Р. М. Баєвського [16]. Аналізували наступні показники: Моду (Мо) - найбільш часте значення кардіоінтервала, характеризує гуморальний канал регуляції і рівень фрункціонування системи; амплітуду моди (АМо) - число значень Мо, виражене у відсотках, відображає стан активності симпатичного відділу; варіаційний розмах $(\mathrm{BP})$ - різницю між максимальним і мінімальним значенням тривалості інтервалів R-R, відображає рівень активності парасимпатичного відділу; індекс вегетативної рівноваги (IBP) - відношення AMo/BP, характеризуе баланс симпатичних i парасимпатичних впливів на серце; показник адекватності процесів регуляції (ПАПР) - відношення AMo/Mo, вказує результативний шлях цен- трального стимулювання (нервовий, або гуморальний); вегетативний показник ритму (ВПР) - характеризуе загальну варіабельність серцевого ритму; індекс напруги (IH) - інтегральний показник, що відображає нейрогуморальну регуляцію і ступінь напруги компенсаторних механізмів, рівень функціонування центрального контуру регуляції ритму серця.

Статистичний аналіз результатів дослідження проводили з використанням пакету прикладних програм «Statistsca 6.0» (StatSoft Inc, США). Дані дослідження кількісних показників перевірялись на нормальність розподілу. Визначали середне значення (M), дисперсію, стандартне відхилення, m - стандартну похибку середнього арифрметичного значення змінної (m), вірогідність та рівень значущості (p). Відмінності вважали достовірними при рівні статистичної значущості $\mathrm{p}<0,05$. Для оцінки взаємозв'язків між досліджуваними показниками використовували метод кореляційного аналізу з обчисленням коефіцієнтів кореляції Пірсона (при нормальному розподілі).

\section{РЕЗУЛЬТАТИ ТА ЇХ ОБГОВОРЕННЯ}

Величина індексу IP у хворих I групи становила $(0,30 \pm 0,02)$, в контрольній групі - $(0,42 \pm 0,01)-\mathrm{p}<0,05$, у хворих II групи - $(0,27 \pm 0,03)-\mathrm{p}<0,05$. При аналізі середніх значень вмісту досліджуваних гормонів у I групі виявлено вірогідне підвищення ТТГ, $\mathrm{T}_{4}, \mathrm{~T}_{3}, \mathrm{KT}$ у порівнянні 3 контрольною групою. Це свідчить про зміну зворотного регуляторного зв'язку між тиреоїдними гормонами, спричиненого порушенням їх конверсії, що може мати компенсаторний механізм, спрямований на посилення поглинання глюкози периферичними тканинами і зменшення IP [15]. У хворих I групи також спостерігалося значиме підвищення вмісту AII і КАП, в той час як АРП суттево не відрізнялася. Така дисоціація змін РААС зумовлена значною перевагою не ренінових і не АПФ-залежних механізмів утворення AII. Крім того, при IP порушується пригнічення інсуліном глюкозостимулюючої експресії гена ангіотензиногену, що може збільшувати синтез
AII [17]. Рівень ККП також вірогідно перевищував показник в контрольній групі. Концентрація ПГ не відрізнялася від такої у здорових, проте була суттєво нижчою, ніж у II групі. Концентрація $\mathrm{Ca}^{2+}$ в групах перебувала в межах редерентних значень, а вміст $\mathrm{Mg}^{2+}$ був вірогідно нижчим, що також могло спричиняти IP через вплив на магній-залежну аденілатциклазу. У вегетативному тонусі виявили перевагу симпатичного відділу: IH (217,79 $\pm 14,39)$ i $(58,64 \pm 4.03)-\mathrm{p}<0,01 ; \operatorname{IBP}(8,91 \pm 0,17)$ i $(3,71 \pm 0,39)-p<0,05$. Активність парасимпатичного відділу не відрізнялася, проте була вірогідно зниженою у порівнянні з II групою: $\mathrm{BP}(0,17 \pm 0,02)$ i $(0,46 \pm 0,02)-$ p $<0,01$. Особливістю взаємодії симпатичного відділу вегетативної нервової системи 3 гормональною ланкою у хворих I групи була наявність кореляційного зв'язку АМо з інсуліном $(r=0,68 ; \mathrm{p}<0,01)$. Очевидно, що інсулін потенціював пресорні механізми катехоламінів. Механізм такого синергіз- 
Вміст гормонів, глюкози, електролітів

Таблиця 1

в плазмі крові здорових осіб та хворих на артеріальну гіпертензію з інсулінорезистентністю

\begin{tabular}{|c|c|c|c|}
\hline \multirow{2}{*}{ Показник } & \multicolumn{3}{|c|}{$\begin{array}{c}\text { Величина показника }(\mathrm{M} \pm \mathrm{m}) \\
\text { у групах }\end{array}$} \\
\hline & $\begin{array}{l}\text { Контрольна } \\
\text { група, } \mathrm{n}=34\end{array}$ & $\begin{array}{l}\text { Хворі на АГ, } \\
\text { І група, } \mathbf{n}=37\end{array}$ & $\begin{array}{l}\text { Хворі на АГ, } \\
\text { II група, n = 31 }\end{array}$ \\
\hline АРП, нг/мл/г & $1,13 \pm 0,15$ & $1,35 \pm 0,14^{\wedge}$ & $1,79 \pm 0,23^{*}$ \\
\hline Альдостерон, пг/мл & $131,14 \pm 13,62$ & $178,54 \pm 12,29 *$ & $153,72 \pm 14,65$ \\
\hline Кальцитонін, пг/мл & $11,19 \pm 2,57$ & $16,08 \pm 2,15^{*}$ & $15,62 \pm 2,38$ \\
\hline Паратгормон, нг/мл & $0,51 \pm 0,03$ & $0,52 \pm 0,04$ & $0,71 \pm 0,05^{*}$ \\
\hline ТТГ, млО/л & $1,05 \pm 0,06$ & $1,34 \pm 0,03^{* *}$ & $1,20 \pm 0,04$ \\
\hline $\mathrm{T}_{4}$, нмоль/л & $81,38 \pm 4,20$ & $107,79 \pm 8,32^{*}$ & $91,73 \pm 6,54$ \\
\hline $\mathrm{T}_{3}$, нмоль/л & $1,28 \pm 0,05$ & $1,52 \pm 0,07 *$ & $1,40 \pm 0,06$ \\
\hline Інсулін, мкОд/мл & $10,05 \pm 1,32$ & $13,72 \pm 1,84$ & $15,77 \pm 1,53^{*}$ \\
\hline Кортизол, нмоль/л & $567,49 \pm 45,31$ & $835,9 \pm 63,17 * *$ & $723,52 \pm 43,94^{*}$ \\
\hline Прогестерон, нг/мл & $6,51 \pm 0,32$ & $6,03 \pm 0,24^{\wedge}$ & $8,11 \pm 0,27 *$ \\
\hline Ангіотензин II, нмоль/л & $35,27 \pm 5,42$ & $51,73 \pm 3,65^{*}$ & $63,14 \pm 5,13^{* *}$ \\
\hline Глюкоза,ммоль/л & $4,18 \pm 0,12$ & $4,15 \pm 0,13$ & $4,37 \pm 0,10$ \\
\hline Іонізований кальцій, ммоль/л & $1,34 \pm 0,12$ & $1,37 \pm 0,15$ & $1,32 \pm 0,14$ \\
\hline Магній, ммоль/л & $1,84 \pm 0,12$ & $1,14 \pm 0,08 *$ & $1,63 \pm 0,14$ \\
\hline
\end{tabular}

Примітки:

$\wedge$ - $\mathrm{p}<0,05$ відносно групи II хворих на артеріальну гіпертензію (АГ),

$*-\mathrm{p}<0,05$,

** — p $<0,01$ відносно осіб контрольної групи.

му міг бути зумовлений здатністю інсуліну збільшувати поглинання натрію і кальцію гладенькими м'язами судин [6].

Встановлений прямий кореляційний зв'язок КТ та рівня IP $(\mathrm{r}=0,52 ; \mathrm{p}<0,01)$. При симпатикотонії КТ проявляе контрінсулярну дію: на пререцепторному рівні (гальмуе секрецію інсуліну), на клітинному рівні знижуе чутливість до інсуліну м'язової і жирової тканини, на рівні печінки посилюе глюконеогенез і глікогеноліз [18]. Характер кореляційного зв'язку може свідчити про взаємозв'язок КТ та інсуліну в регуляції вуглеводного обміну, посередником якого є система аденілатциклази і вміст внутрішньоклітинного $\mathrm{Ca}^{2+}$ [18]. Реалізація ефектів КТ зумовлена зростанням внутрішньоклітинного $\mathrm{Ca}^{2+}$, активацією аденілатциклазної системи і накопиченням в клітинах-мішенях цАМФ. Крім того, підвищена активність медіаторної ланки $\mathrm{CAC}$ через активацію адренорецепторів ак- тивізуе гуанілатциклазну систему цГМФ, а дефіцит $\mathrm{Mg}^{2+}$ в першу чергу впливае на активність магній-залежної аденілатциклази. Виникае дисбаланс в системі цАМФ/ цГМФ. Гіперінсулінемія через посилене виведення $\mathrm{Mg}^{2+}$ із клітин гальмуе фоссфорилювання GLUT-4, що знижуе захват глюкози клітинам [7]. Також гіперактивність CAC супроводжуеться зниженням рівня внутрішньоклітинного $\mathrm{Mg}^{2+}$. Понижений рівень $\mathrm{Mg}^{2+}$ може спричиняти IP, а послаблена відповідь на інсулін зменшуе транспорт $\mathrm{Mg}^{2+}$ в клітини. Рівень $\mathrm{T}_{3}$ зворотно корелював із показником IP ( $\mathrm{r}=-0,57$; $\mathrm{p}<0,01)$, в той час як в контрольній групі між цими показниками визначався прямий зв'язок $(\mathrm{r}=0,62 ; \mathrm{p}<0,01)$. Така зміна кореляційного зв'язку може бути наслідком переважного впливу $\mathrm{T}_{3}$ на глюкогенез і глікогеноліз в контрольній групі і більшою залежністю периферичних ефектів $\mathrm{T}_{3}$ від стану інсулінорезистентності у хворих на АГ. 
У хворих на АГ II групи у порівнянні 3 контрольною виявлено вірогідне підвищення ПТГ. Концентрація $\mathrm{Ca}^{2+}$ i $\mathrm{Mg}^{2+}$ в крові суттево не відрізнялись. Також виявлено вірогідне підвищення АРП, АІІ, ККП, IPI у порівнянні з контрольною групою. Крім того, рівень АРП значимо перевищував показник у хворих I групи, що зумовлено, ймовірно, активацією ренінових і АПФ-залежних механізмів синтезу AII. Концентрація ПГ вірогідно перевищувала показник в контрольній групі. У вегетативному тонусі спостерігався дисбаланс з підвищенням парасимпатичної активності: BP $(0,46 \pm 0,02)$ i $(0,15 \pm 0,02)-p<0,01$; активність автономного і центрального рівнів регуляції не відрізнялась від такої в контрольній групі. Спостерігався зворотний кореляційний зв'язок між ПТГ і індексом IP ( $\mathrm{r}=-0,53 ; \mathrm{p}<0,01)$, у контрольній групі між ПТГ і індексом маси тіла $(\mathrm{r}=-0,46 ; \mathrm{p}<0,05)$. Також визначався вірогідний кореляційний зв'язок між ступенем парасимпатикотонії (BP) і IPI ( $r=0,64$; $\mathrm{p}<0,01)$. Патогенетична суть зазначених гормональних змін, очевидно, полягає у тому, що при гіперінсулінемії інгібіруються $\mathrm{Ca}^{2+} / \mathrm{Na}^{+} / \mathrm{K}^{+}$насоси і активуеться $\mathrm{Na}^{+} / \mathrm{K}^{+}-$ протитранспорт в м'язових клітинах, що забезпечуе підвищення ї скоротливості [6]. У хворих II групи встановлено кореляційний зв'язок АРП з маркером IP ( $\mathrm{r}=0,41$; $\mathrm{p}<0,05)$, в контрольній групі між цими показниками визначався зворотний зв'язок $(\mathrm{r}=-0,64 ; \mathrm{p}<0,01)$. Характер виявлених кореляцій, очевидно, свідчить про порушення механізму зниження інсулінозалежної затримки натрію в нирках при збільшенні його концентрації.

Таким чином, проведене дослідження дозволило виявити не тільки особливості нейрогуморальних профілів у хворих на АГ з IP залежно від вегетативного тонусу, але і встановити відмінні ознаки в структурі взаемозв'язків нейрогуморальних регуляторів, показників вуглеводного обміну і міжгормональних взаемодій. Вплив кальцій-регулюючих гормонів на розвиток IP у хворих на АГ залежить від вегетативного тонусу. У хворих на АГ із парасимпатикотонією регуляторні ефекти ПТГ опосередковані вмістом $\mathrm{Ca}^{2+}$ в крові, а його зниження пропорційне толерантності до глюкози. При симпатикотонії КТ проявляе контрінсулярну дію на різних рівнях. Існуе тісний взаємозв'язок між тиреоїдними і кальційрегулюючими гормонами, інсуліном в регуляції вуглеводного обміну і формуванні IP, посередниками якого е вміст внутрішньоклітинного $\mathrm{Ca}^{2+}$ i $\mathrm{Mg}^{2+}$, система аденілатциклази. Механізм взаємодії інсуліну і ренін-ангіотензин-альдостеронової системи при АГ з IP залежить від концентрації гормонів, глюкокортикоїдної функції наднирників, активності вегетативної нервової системи, що слід враховувати при призначенні диференційованої антигіпертензивної терапії.

\section{ВИСНОВКИ}

1. У хворих на АГ з IP визначаються особливості гормонального профілю залежно від вегетативного тонусу: при симпатикотонії підвищений вміст катаболічних гормонів (ТТГ, $\mathrm{T}_{4}, \mathrm{~T}_{3}$, КТ, ККП, КАП), при парасимпатикотонії - анаболічних гормонів (інсуліну, ПТГ, ПГ).

2. Проведене дослідження дозволило виявити не тільки особливості нейрогуморальних профілів у хворих на АГ з IP залежно від вегетативного тонусу, але і встановити відмітні кореляційні зв’язки між нейрогуморальними регуляторами, показниками вуглеводного обміну та вегетативного тонусу.
3. Нейрогуморальний профіль і міжгормональні взаємодії при АГ впливають на механізми формування IP залежно від вегетативного тонусу. При перевазі парасимпатичного тонусу, ймовірно, переважають рецепторні і пострецепторні механізми IP (низький рівень внутрішньоклітинного $\mathrm{Ca}^{2+}$ при високому ПТГ, порушення пермісивної дії глюккортикоїдів, антирецепорні антитіла), при АГ з симпатикотоніею - на рівні клітинмішеней інсулінчутливих тканин (високий рівень внутрішньоклітинного $\mathrm{Ca}^{2+}$ при високому КТ, низький рівень $\mathrm{Mg}^{2+}$, дисбаланс в системі цАМФ/цГМФ, контр- 
інсулярний вплив КТ). З'ясування конкретних молекулярних механізмів формування IP у хворих на АГ з різним вегетативним тонусом потребуе подальшого вивчення.

\title{
ЛITEPATУРA \\ (REFERENCES)
}

1. Ormazabal V, Nair S, Elfeky O, et al. Cardiovascular Diabetol 2018;17(1): 122-136. https://doi.org/10.1186/ s12933-018-0762-4.

2. Zhou D, Xi B, Zhao M, et al. Sci Rep 2018;8(1): 9418. https://doi.org/10.1038/s41598-018-27377-2.

3. Pashentseva AV, Verbovoy AF, Sharonova LA. Obes Metabol 2017;14(2): 9-17. https://doi.org/10.14341/omet201729-17.

4. Sokolova LA, Ievskaia EV, Vavilova TV, et al. Arterial Hypertens 2017; 23(4): 294-302. https://doi.org/10. 18705/1607-419X-2017-23-4-294-302.

5. Statsenko ME, Derevyanchenko MV. Rus J Cardiol 2020;25(4): 27-34. https://doi.org/10.15829/1560-40712020-3752.

6. Zhou M, Schulman I, Zeng Q. Vasc Med 2012;17(5): 330341. https://doi.org/10.1177/1358863X12450094.

7. Gutiŭrrez-Rodelo C, Roura-Guiberna A, Olivares-Reyes JA. Gac Med Mex 2017;153(2): 214-228.

8. Balu D, Ouyang J, Parakhia RA, et al. Front Endocrinol (Lausanne) 2020;25: 11-33. https://doi.org/10.3389/fendo.2020.00033.

9. Mancusi C, Izzo R, Giuseppe di Gioia G, et al. High Blood Press Cardiovasc Prev 2020;27(6): 515-526. https://doi.org/10.1007/s40292-020-00408-8.
10. Williams B, Mancia G, Spiering W, et al. Eur Heart J 2018;39(33): 3021-3104. https://doi.org/10.1093/eurheartj/ehy339.

11. Gao P, Hu Y, Wang J, et al. Med Sci Monit 2020;11(26): e924334. https://doi.org/10.12659/MSM.924334.

12. Kurt Hшjlund. Dan Med J 2014;61(7): B4890.

13. Osegbe I, Okpara H, Azinge E. Ann African Med 2016; 15(1): 14. https://doi.org/10.4103/1596-3519.158524.

14. Forrester SJ, Booz GW, Sigmund CD, et al. Physiol Rev 2018;98(3): 1627-1738. https://doi.org/10.1152/physrev.00038.

15. Korchynski V. Ukr J Cardiol 2014;6: 60-65.

16. Baevsky RM. et al. Analysis of heart rate variability using various electrocardiographic systems: method. Recommendations, Moskva, 2002: 53 p.

17. Zhang S, Wei M, Yue M, et al. Endocrine 2018;62(3): 588-601. https://doi.org/10.1007/s12020-018-1700-7.

18. Moisa S. J Biomed Sci Engineering 2017;10(7): 343-354. https://doi.org/10.4236/jbise.2017.107026.

\section{НЕЙРОГУМОРАЛЬНІ ПРОФІЛІ ТА ІНСУЛІНОРЕЗИСТЕНТНІСТЬ У ХВОРИХ НА АРТЕРІАЛЬНУ ГІПЕРТЕНЗІЮ БЕЗ ОЖИРІННЯ}

\author{
Шевчук С. В. ${ }^{1}$, Корчинський В. С. ${ }^{2}$
}

\author{
${ }^{1}$ Науково-дослідний інститут реабілітації осіб з інвалідністю \\ Вінницького національного медичного університету ім. М. І. Пирогова, \\ м. Вінниия, Україна \\ ${ }^{2}$ Вінницький інститут університету «Україна», \\ м. Вінниия, Украӥна \\ doktor.k.v.s@gmail.com
}

Мета дослідження: вивчення показників вуглеводного обміну, активності ренін-ангіотензин-альдостеронової системи (РААС), глюкокортикоїдної функції наднирників, кальцій-регулюючих і тиреоїдних гормонів і їх можливих взаємозв'язків у хворих на артеріальну гіпертензію (АГ) з інсулінорезистентністю (IP) в залежності від стану вегетативного тонусу.

Матеріали та методи. Проведено комплексне дослідження гормонального профілю радіоімунним методом і вегетативного тонусу у 68 хворих на АГ II стадії, 1-2 ступеня, чоловічої статі (середній

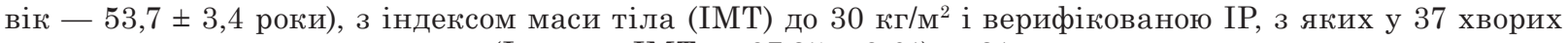
переважав симпатичний тонус (I група, IMT $-27,35 \pm 2,61)$, у 31 хворого - парасимпатичний тонус (II група, IMT - 26,43 $\pm 2,85$ ). Інсулінорезистентність верифікували за величиною індексу Саго (глюкоза, ммоль/л/ інсулін, мкОд/мл), що не перевищувала 0,33. Для оцінки стану вегетативної нервової системи проводили варіаційну пульсометрію.

Результати. В ході дослідження встановлено, що у хворих на АГ з IP при симпатикотонії підвищений вміст катаболічних гормонів: тиреотропного гормону, тироксину, трийодтироніну, кортизолу, кальцитоніну, альдостерону, при парасимпатикотонії - анаболічних гормонів: інсуліну, паратгормону, прогестерону. Існуе тісний взаємозв'язок між тиреоїдними і кальцій-регулюючими гормонами, інсуліном в регуляції вуглеводного обміну і формуванні IP, посередниками якого є система аденілат- 
циклази, вміст внутрішньоклітинного $\mathrm{Ca}^{2+} \mathrm{i} \mathrm{Mg}^{2+}$. Вплив кальцій-регулюючих гормонів на розвиток IP у хворих на АГ залежить від вегетативного тонусу. Механізми взаемодії інсуліну і РААC при АГ з IP залежать від концентрації гормонів, глюкокортикоїдної функції наднирників, активності вегетативної нервової системи.

Висновки: нейрогуморальний профіль і міжгормональні взаємодії при АГ впливають на механізми формування IP залежно від вегетативного тонусу: при перевазі парасимпатичного тонусу, ймовірно, переважають рецепторні і пострецепторні механізми IP, при АГ з симпатикотонією — на рівні клітин-мішеней інсулін-чутливих тканин.

К л ючові слов а: артеріальна гіпертензія, інсулінорезистентність, нейрогуморальні профілі.

\title{
NEUROHUMORAL PROFILES AND INSULIN RESISTANCE IN PATIENTS WITH ARTERIAL HYPERTENSION WITHOUT OBESITY
}

\author{
S. Shevchuk ${ }^{1}$, V. Korchynskyi ${ }^{2}$ \\ ${ }^{1}$ Research Institute of Rehabilitation of National Pirogov Memorial Medical University, \\ Vinnytsia, Ukraine \\ ${ }^{2}$ Vinnytsia Institute of the University "Ukraine», \\ Vinnytsia, Ukraine \\ doktor.k.v.s@gmail.com
}

Studying indices of carbohydrate metabolism, activity of renin-angiotensin-aldosterone system (RAAS), adrenal glucocorticoid function thyroid and calcium-regulating hormones and their possible relationships in patients with hypertension (AH) with insulin resistance (IR) depending on the state of autonomic tone.

Materials and methods. A comprehensive study of hormonal profile and vegetative tonus radioimmune method in 68 patients was held: with arterial hypertension stage II, 1-2 degrees, male (mean age $53.7 \pm 3.4$ years), with a body mass index (BMI) up to $30 \mathrm{~kg} / \mathrm{m}^{2}$ and verified insulin resistance, of which in 37 patients sympathetic tonus dominated (group I, BMI - 27,35 $\pm 2,61$ ), and in 31 patients - parasympathetic tonus dominated (group II, BMI $-26,43 \pm 2,85$ ). Insulin resistance was verified by the value of the Caro index, which did not exceed 0.33 . Variation pulsometry was performed to assess the state of the autonomic nervous system.

Results. It is established that patients with hypertension with IR and sympathicotonia had increased level of catabolic hormones: thyroid-stimulating hormone, thyroxine, triiodothyronine, cortisol, calcitonin, aldosteron, whereas those with parasympathicotonia had increased level of anabolic hormones: insulin, parathyroid hormone, progesterone. There is a strong relation between thyroid and calcium-regulating hormones, insulin in the regulation of carbohydrate metabolism, mediated by the adenylate cyclase system, the content of intracellular $\mathrm{Ca}^{2+}$ and $\mathrm{Mg}^{2+}$. The effect of calcium-regulating hormones on the development of IR in patients with hypertension depends on autonomic tone. The mechanisms of interaction of insulin and renin-angiotensin-aldosterone system in hypertension with IR depend on the concentration of hormones, glucocorticoid function of the adrenal glands, and activity of the vegetative nervous system.

Conclusion: in hypertension with a predominance of sympathetic tonus, probably receptor and postreceptor mechanisms of IR dominate, whereas in hypertension with a predominance of parasympathetic tone those at the level of target cells dominate.

Key words: arterial hypertension, insulin resistance, neurohumoral profiles. 